\title{
Proaktif insan kaynakları yönetiminin yeni gücü: İK analitiği ve yapay zekâ
}

\author{
The new power of proactive human resources management: HR \\ analytics and artificial intelligence (AI)
}

${ }^{1}$ Doç. Dr., Yıldız Teknik Üniversitesi,

yaseminmutluay@gmail.com

ORCID: 0000-0002-3718-3424

2 Dr. Öğr. Üyesi, Yıldız Teknik Üniversitesi, İstanbul, Türkiye, mert.bal@gmail.com

ORCID: 0000-0001-6250-929X

Sorumlu Yazar/Corresponding Author:

Yasemin Bal,

Yıldız Teknik Üniversitesi, İstanbul, Türkiye, yaseminmutluay@gmail.com

Başvuru/Submitted: 9/06/2021

Revizyon/Revised: 30/08/2021

Kabul/Accepted: 5/09/2021

Yayın/Online Published: 25/09/2021

Atıf/Citation: Bal, Y., \& Bal, M., Proaktif insan kaynakları yönetiminin yeni gücü: İK analitiği ve yapay zekâ, bmij (2021) 9 (3): 1198-1216, doi: https://doi.org/10.15295/bmij.v9i3.1863

\author{
Yasemin Bal ${ }^{1}$ \\ Mert Bal ${ }^{2}$
}

Öz

IK Analitiği son yıllarda giderek önem kazanan konular arasında yer almaktadır. Kurumun insan kaynaklarına ilişkin verilerini analiz etmek, sorunlarını tespit etmek ve strateji belirlemek için kullanılan İK Analitiği kurumlara önemli bir rekabet avantajı sağlamaktadır. İK analitiği, işletmelerin elektronik tablo tabanlı veri deposundan uzaklaşmasını sağlayarak, verileri gerçek zamanlı olarak tutmaya ve bunları kurumun mevcut veri akışı ile birlikte analiz etmeye imkân tanımaktadır. Yapay zekâ yöntemlerinin bu alanda kullanılması ile verimlilik ve tasarruf artışı sağlayan IKK analitiği alanına her geçen gün daha fazla işletme yatırım yapmaktadır. Geliştirilen İK analitiği modülleri ile işletmeler İK süreçlerini daha etkin şekilde yönetebilmekte, işe alım kararlarını daha sağlıklı verebilmekte, işten ayrılma niyeti olan çalışanları önceden tahmin edebilmekte, geleceğe yönelik işgücü optimizasyonu ve planlamalarını daha etkin biçimde yapabilmektedir. Böylece, İK analitiği sayesinde veri temelli karar vermek ve strateji belirlemek kolaylaşmaktadır. Bu çalışma kapsamında İK analitiği kavramının önemi incelenecek ve İK fonksiyonlarının hangi süreçlerinde İK analitiğinden yararlanıldığı, hangi yapay zekâ yöntemlerinin bu alanda nasıl kullanıldığı ve işletmelere ne gibi yarar sağladığı üzerinde durulacaktır. Gerek İK analitiği gerekse yapay zekâ konularının işletmecilik alanında giderek yükselen bir trend kazanması, bununla beraber yerli literatürde İK Analitiği ve Yapay Zekâ konusunu birlikte ele alan ve işletmelere kattığı değer yönünden inceleyen teorik pek fazla çalışmanın bulunmaması bu çalışmanın önemini oluşturmaktadır. Çalışma özellikle ilgili alanda çalışan akademisyenler ile uygulamacılara yol gösterici olacaktır.

Anahtar Kelimeler: İnsan Kaynakları Yönetimi, İK Analitiği, Yapay Zekâ, Makine Öğrenme, Derin Öğrenme, Yapay Sinir Ağları

Jel Kodları: M10, M12

\begin{abstract}
HR Analytics is among the topics that have become increasingly important in recent years. HR Analytics, which is used to analyze the institution's human resources data, identify the problems, and determine the strategy, provides a significant competitive advantage. HR analytics enables businesses to move away from a spreadsheet-based data repository, allowing keeping data in realtime and analyzing it together with the existing data flow of the organization. With artificial intelligence methods in this field, more and more businesses are investing in HR analytics, which provides increased efficiency and savings. With the HR analytics modules developed, businesses can manage their HR processes more effectively, make better recruitment decisions, anticipate employees who intend to leave, and make workforce optimization and planning for the future more effectively. Thus, thanks to HR analytics, it becomes easier to make data-based decisions and determine strategies. Within the scope of this study, the importance of HR analytics will be examined, and it will be emphasized in which HR functions HR analytics are used, which artificial intelligence methods are used in this field and how they benefit businesses. The importance of this study is that both HR analytics and artificial intelligence are gaining an increasing trend in business. Few theoretical studies in the literature deal with HR Analytics and Artificial Intelligence and examine them in terms of their value to businesses. The study guides academics and practitioners working in the relevant field.
\end{abstract}

Keywords: Human Resources Management, HR Analytics, Artificial Intelligence, Machine Learning, Deep Learning, Neural Networks

Jel Codes: M10, M12 


\section{Extended Abstract}

\section{The new power of proactive human resources management: HR analytics and artificial intelligence} (AI)

\section{Literature}

The fourth industrial revolution has fundamentally changed the way people live, work and relate to one another. Smart Human Resources 4.0 (SHR 4.0) is part of the Industry 4.0 new concept. Innovations in digital technologies such as cloud computing, Big Data, Internet of Things (IoT), Robotic Process Automation (RPA), artificial intelligence and fast data used in Smart HR 4.0 have increased the effective management of companies' new generation employees (Karmanska, 2020). In today's competitive business life and rapidly changing environmental conditions, traditional human resources practices are insufficient in many processes. With the understanding of strategic human resources management that is gaining importance, HR departments today need to adapt to businesses' main goals and strategies, design HR processes to support and implement the institution's strategies, and determine their strategies. In this direction, HR departments should provide added value to the institution to determine the strategy and decision-making for the future. Analytics is defined as the intersection of computer science, decision-making, and quantitative methods to organize, analyze, and explain the increasing amount of data produced by modern society (Mortensen, Doherty and Robinson, 2015). Adding the "human resources" component to this definition shows that this analyzes concern people within the organization (Heuvel and Bondarouk, 2017). HR analytics includes different processes and applications in itself; it is interdisciplinary solid as it brings together both HR and business data to analyze people-related risks, performance characteristics, commitment and culture and identifies career paths (Margherita, 2020). Although HR Analytics has been discussed for years, it represents an emerging trend and innovation. Therefore, it seems appropriate to consider HR analytics a widespread innovation (Marler and Boudreau, 2017). One of the main reasons HR analytics has gained importance is the adoption of data-driven approaches in business to be processed and interpreted for meaningful insights in human resources. Artificial Intelligence (AI) creates excellent HR analytics opportunities in practical terms (Sooraksa, 2021). This data analysis method takes data routinely collected by HR and then relates it to HR and organizational goals. Thus, it is possible to provide measurable evidence of how HR processes and functions contribute to the goals and strategies of the organization and to what extent they create value for the organization.

\section{Research subject}

The research aims to examine how modern and technological methods such as HR analytics and artificial intelligence benefit from traditional methods in human resource management, which is gaining importance and taking on a proactive role.

\section{Contribution of the article to the literature}

The importance of this study is that both HR analytics and artificial intelligence are gaining an increasing trend in the field of business administration and finding application areas and that there are not many theoretical studies in the national literature that deal with HR Analytics and Artificial Intelligence together and examine them in terms of the value they add to businesses.

\section{Design and method}

The study reviews a wide variety of literature related to HR analytics and artificial intelligence. The importance of HR analytics, how it is used in which areas of human resource management, and its benefits were investigated by scanning the international literature. In addition, how artificial intelligence methods are used in human resources and which artificial intelligence methods are used in what HR processes are examined.

\section{Findings and discussion}

It is essential for HR departments that are faced with massive data to analyze and interpret this data, make predictions for the future, and design HR processes according to the needs and expectations of the institution. HR analytics increases employee performance, attracts talented candidates to the company and retains high-performing employees. Powered by data-based knowledge, HR can thus fulfil its role as a strategic partner. Instead of traditional HR applications that make inferences by evaluating historical data, it is possible to make future predictions with data processing techniques in new HR analytics models enriched with artificial intelligence. As a result, HR functions and applications can be designed in line with the institution's needs. HR managers can make future projections and include applications that add value to the organization thanks to the HR analytics modules primarily developed with artificial intelligence methods. Thus, HR departments can reveal their added value with statistical results and figures, such as finance, marketing, and production. With the help of artificial intelligence methods used in HR Analytics, workforce planning can be done in terms of quality and quantity according to business strategies and targets. Resumes can be scanned to identify suitable candidates for the job requirements, and then the right candidates can be selected and matched with the correct positions. High-performing talented employees can be identified, career planning and training development suggestions can be created for these talented employees. As a result, with the correct implementation of all these processes, employee loyalty can be increased. Forecasts can also be made, employees who intend to leave the job can be determined in advance, practices that increase employee motivation can be determined, and a strategy can be developed for retaining talented employees.

\section{Conclusion and recommendation}

Considering that human resources are the most critical competitive power source of institutions today, it is indisputable how much advantage and power all these outputs obtained thanks to HR Analytics, and artificial intelligence will provide to businesses. Within the scope of this study, we examined HR analytics and artificial intelligence as the new trends that have been effective in gaining a more strategic and proactive role in human resources management by exemplifying the advantages it provides in terms of all HR functions and processes. We expect the information presented in the study to guide both scientists working in this field and practitioners working in the field of human resources.

\section{Suggestions based on results}

We think that essential topics such as HR analytics and artificial intelligence, which are developing day by day and find application in new fields, will become more widespread, and it is necessary to carry out theoretical and empirical studies in these areas. 


\section{Limitations of the article}

The limitation of the study is that it only deals with the subject in a theoretical framework and cannot present empirical application results and examples. However, in future studies, it is considered to give examples from HR practices, especially in Turkish businesses. 


\section{Giriş}

Dördüncü sanayi devrimi, insanların yaşama, çalışma ve birbirleri ile ilişki kurma biçimlerini temelden değiştirmiştir. Akıllı İnsan Kaynakları 4.0 (SHR 4.0), Endüstri 4.0 yeni konseptinin bir parçasıdır. Akıllı HR 4.0'da kullanılan bulut bilişim, Büyük Veri, Nesnelerin İnterneti (IoT), Robotik Süreç Otomasyonu (RPA), yapay zekâ (AI) ve hızlı veri gibi dijital teknolojilerdeki yenilikler, şirketlerin yeni nesil çalışanlarının etkin yönetimini artırmıştır (Karmanska, 2020). Günümüzün rekabetçi iş yaşamında ve hızla değişen çevre koşullarında geleneksel insan kaynakları uygulamaları birçok süreçte yetersiz kalmaktadır. Giderek önem kazanan stratejik insan kaynakları yönetimi anlayışı ile beraber İK departmanlarının bugün işletmelerin ana hedef ve stratejilerine uyum sağlaması, kurumun stratejilerini destekleyip, hayata geçirecek şekilde İK süreçlerini tasarlamasını ve kendi stratejilerini belirlemesi gerekmektedir. Bu doğrultuda geleceğe yönelik strateji belirleme ve karar verme noktasında İK departmanları kuruma katma değer sağlamalıdır. Her an büyük veri yığını ile karşı karşıya kalan İK departmanları için bu verileri analiz edebilmek, yorumlayabilmek, geleceğe dönük öngörüler de bulunup, İK süreçlerini kurumun ihtiyaç ve beklentilerine göre tasarlamak oldukça önem kazanmaktadır. İK analitiği sayesinde çalışan performansı artmakta, yetenekli adaylar işletmeye çekilebilmekte ve yüksek performanslı çalışanlar elde tutulabilmektedir. Veriye dayalı bilgi ile güçlendirilen İK böylece stratejik ortak olma rolünü yerine getirebilmektedir. Geçmiş verileri değerlendirerek çıkarımlar yapan geleneksel İK uygulamaları yerine yapay zekâ ile zenginleştirilmiş yeni İK analitiği modellerinde veri işleme teknikleri ile geleceğe dönük öngörüler yapabilmek mümkün olabilmekte ve İK fonksiyonları ile uygulamaları da kurumun ihtiyaçları doğrultusunda tasarlanabilmektedir.

Çoğunlukla yapay zekâ yöntemleri ile geliştirilen İK analitiği modülleri sayesinde İK yöneticileri geleceğe dönük projeksiyonlar yapabilmekte ve kuruma değer katan uygulamalara yer verebilmektedir. Böylece İK departmanları da bugün İK analitiği sayesinde finans, pazarlama ve üretim departmanları gibi istatistiki sonuçlarla ve rakamlarla kendi katma değerini ortaya koyabilmektedir. İK Analitiğinde kullanılan yapay zekâ yöntemleri sayesinde; işletme strateji ve hedeflerine göre nitelik ve nicelik olarak işgücü planlaması yapılabilmekte, iş gereklerine uygun adayları belirme amacı ile özgeçmişler taranabilmekte, doğru adaylar seçilip doğru pozisyonlar ile eşleştirilebilmekte, yüksek performans gösteren yetenekli çalışanlar tespit edilebilmekte, kariyer planlama ve eğitim geliştirme önerileri oluşturulabilmekte, çalışan bağlılı̆̆ını arttırmaya yönelik öngörüler de yapılabilmekte, işten ayrılma niyetinde olan çalışanlar önceden tespit edilebilmekte, çalışan motivasyonunu arttıran uygulamalar belirlenebilmekte ve yetenekli çalışanları elde tutma konusunda strateji geliştirilebilmektedir. İnsan kaynağının günümüzde kurumların en önemli rekabetçi güç kaynağı olduğu dikkate alındığında, İK Analitiği ve yapay zekâ sayesinde elde edilen tüm bu çıtılırın işletmelere ne denli avantaj ve güç sağlayacağı tartışılmazdır.

\section{İK analitiği kavramına genel bakış}

Analitik, modern toplum tarafından üretilen artan miktarda veriyi organize etmek, analiz etmek ve açıklamak için bilgisayar bilimi, karar verme ve nicel yöntemlerin kesişimi olarak tanımlanmaktadır (Mortensen, Doherty ve Robinson, 2015). Bu tanıma "insan kaynakları" bileşeninin eklenmesi ise, bu analizlerin kurum içindeki insanları ilgilendirdiğini göstermektedir (Heuvel ve Bondarouk, 2017). Kendi içinde farklı süreçleri ve uygulamaları içeren IK analitiği; insanlarla ilgili riskleri, performans özelliklerini, bağlılığı ve kültürü analiz etmek ve kariyer yollarını belirlemek için hem İK hem de işle ilgili verileri bir araya getirdiği için disiplinler arası güçlü bir yapıya sahiptir (Margherita, 2020).

Geleceğe dönük öngörülerde bulunmak, strateji belirlemek ve fırsatlardan yararlanabilmek için kuruma yararlı bilgileri sağlayabilecek doğru verileri bulabilmek, bu verileri analiz edebilmek, veriler arasındaki bağlantıları ve örüntüleri tespit edebilmek ve bunların ışı̆̆ında karar verebilmek bugün tüm işletmeler için en değerli unsur olarak görülmektedir. Geleneksel insan kaynakları yönetimini düşündüğümüzde, İK departmanları kuruma yarattıkları değeri somut olarak göstermede ve katkısını rakamlarla ifade etmede yetersiz kalmıştır. Ancak bugün insan kaynakları yönetiminin proaktif bir role bürünerek, giderek stratejik bir ortak olarak önem kazanması ile beraber özellikle İK analitiği gibi yeni uygulamalar sayesinde artık İK departmanları da veriden anlam çıarabilmekte, yarattıkları gücü ve değeri somut olarak rakamlarla üst yönetime sunabilmektedir.

Son yıllarda, İK analitiği, insan kaynakları yönetimi alanındaki uygulayıcılar ve danışmanlar arasında büyük ölçüde popülerlik kazanmıştır. İK analitiği literatürde aynı zamanda yetenek analitiği, insan analitiği ve işgücü analitiği olarak da adlandırılmaktadır. "Bir kurumun işgücü performansını iyileştirmek için insan kaynaklarma ilişkin verileri toplama ve analiz etme süreci" olarak ifade edilen İK Analitiği, eyleme dönüştürülebilecek iç görüler oluşturmak ve bir kurumun iş gücünü, çalışanlarını ve/veya 
yetenek yönetimi performansını iyileştirmek için İK verilerini toplamaya, izlemeye ve analiz etmeye odaklanmaktadır. İK analitiği ile ilgili bir dizi kilit unsur vurgulanmaktadır; insanlarla ilgili karar vermede kanıta dayalı bir yaklaşımdır; İK verilerinin sistematik analiz ve görselleştirme yöntemlerini benimser; yöneticilerin ve üst düzey karar vericilerin ihtiyaçlarına hizmet eder; geniş bir potansiyel etki yelpazesine sahip çok süreçli ve çok uygulamalı bir çabadır (Margherita, 2020).

Farklı analitik biçimleri; tanımlayıcı analitik, teşhis edici analitik, tahmin edici analitik ve yönergeli (optimize edici) analitik olarak kategorize edilebilmektedir. Tanımlayıcı analitik, İK analitiğinin ilk seviyesidir. Geçmişteki davranışların ve sonuçların anlaşılmasına imkân vermektedir (Fitz-enz, 2009). Modellere anlam yüklemeden veriler arasındaki ilişkileri aramakta ve tanımlamaktadır. Dolayısıyla tanımlayıcı analitik, öngörüden ziyade keşif amaçlı olmaktadır ve geçmişten gelen trendleri vermektedir. "Ne oldu?" sorusuna cevap veren tanımlayıcı analitik ile geçmişe dönük verileri anlamak mümkün olurken, teşhis edici analitik ile "neden oldu?" sorusuna cevap arayıp içgörü geliştirilmektedir. Ancak bugünün ve yarının hızla değişen piyasalarında geçmişi geleceğe yansıtmak ve bu doğrultuda tahminlemeler yapmak oldukça risklidir. Tahmin edici analitik ile geleceğe dönük tahmin yapmaya yönelik "ne olacak?" sorusuna cevap aranmaktadır. Tahmin edici analitik; karar ağaçları, genetik algoritmalar, yapay sinir ağları gibi yöntemleri; tanımlayıcı analitik ise veri görselleştirme, gösterge tabloları/puan kartları, OLAP raporları, yayınlanmış raporlar ve SQL sorgularının kullanımını içermektedir. İK Analitiği araçları, insan kaynakları süreçlerinde karar vermeyi kolaylaştırmak amacıyla tahmin edici analitik için kullanılabilmektedir. Tanımlayıcı analitik mevcut veri kalıplarını ortaya çıkarırken, tahmin edici analitik bu kalıplara gelecek için anlam vermektedir. Tahmin edici analitik sayesinde, tarihsel verilere bakarak gelecekteki bir olayın gerçekleşme olasılığını önceden söylemek bir derece mümkün olabilmektedir (Fitz-enz, 2009). “Ne olacak?" ve "neden olacak?" sorularına yanit veren tahmin edici analitik, kullanıcının olması muhtemel olanı tahmin etmesine olanak sağlayarak verileri çok daha somut bir şekilde kavramasını sağlamaktadır. Tahmin edilebileceği gibi, bu araçlar çok güçlüdür ve doğru uygulandığında karar vermeyi doğrudan etkileme potansiyeline sahiptir. Örneğin, hangi çalışanların işletmeden ayrılacağı veya eğitim-geliştirmeye yapılan yatırımların gelecek yılın performansını nasıl etkileyeceği tahmin edilmek istendiğinde, tahmin edici İK analitiği uygulanmalıdır. Bu tür analitikler, regresyon analizi, karar ağaçları, sinir ağları ve Naive Bayes gibi daha gelişmiş makine öğrenme yöntemlerinden yararlanmaktadır. Bu yöntemleri kullanabilmek için istatistik ve veri analizinde ileri düzeyde uzmanlık ve bilgi birikiminin yanı sıra SPSS, $R$ ve Weka gibi araçların kullanımı da gerekli olmaktadır (Van Vulpen, 2019). Yönergeli analitik ise matematiksel programlama ve simülasyon vb. yöntemleri içermektedir. Yönergeli analitik ile öngörü sağlanarak, "bunu nasıl gerçekleştirebiliriz?" sorusuna yanıt bulup, strateji geliştirilebilmektedir. Şekil 1'de Analitik Üstünlük Modeli verilmektedir. Tahmin edici analitik ve yönergeli analitik seviyelerine çıkıldıkça bu yöntemlerin zorluk derecelerinin artması ile beraber işletmelere getirdikleri yararlar ve kattıkları değerler de artmaktadır.

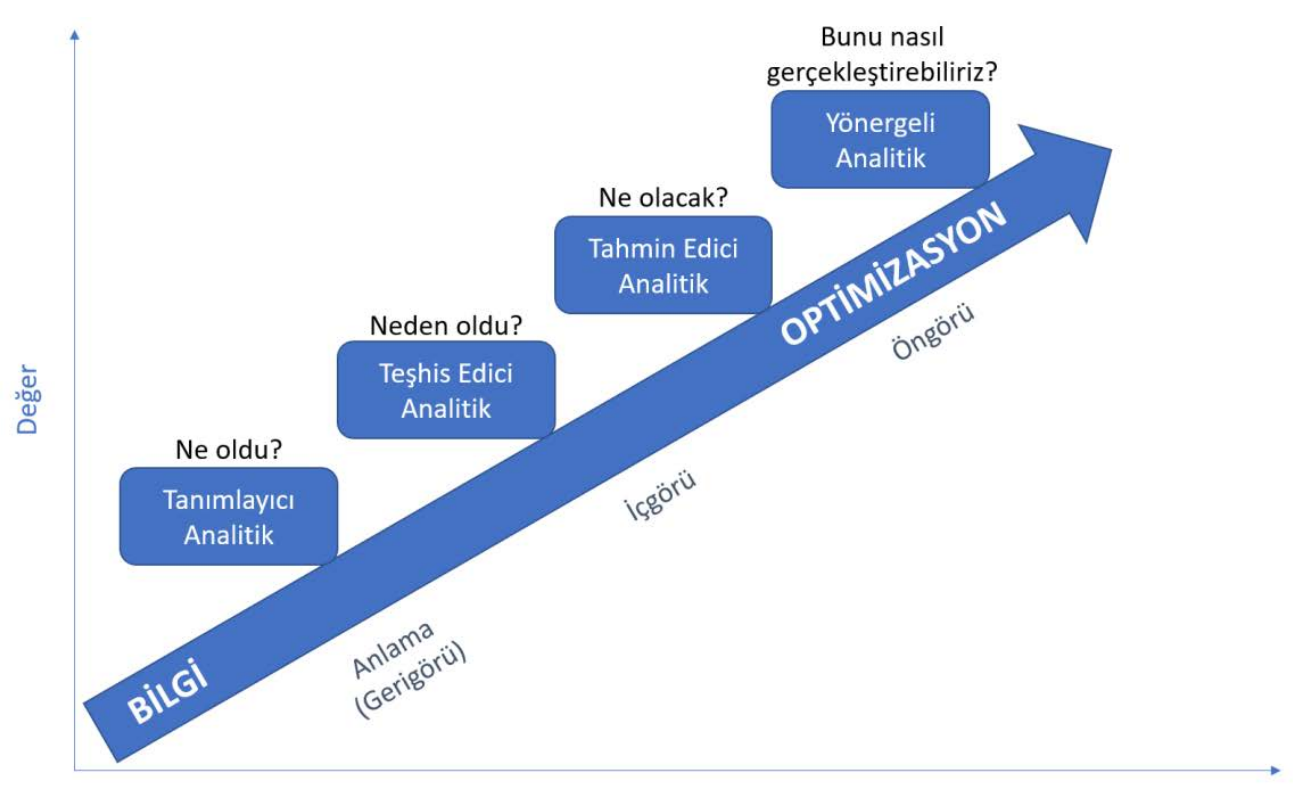

Zorluk

Şekil 1: Analitik Üstünlük Modeli

Kaynak: Gartner Analytics Maturity Model, 2021 
İşletmeler, açık pozisyonları için taranması gereken çok sayıda iş başvurusu almaktadır. Tahmin edici analitik, yüksek iş performansı için gereken nitelikleri belirlemek ve böylece çeşitli iş pozisyonları için başvuran adayları taramak için kullanılabilmektedir. Tahmin edici analitik kullanılarak her iş başvurusu değerlendirilmekte, ancak yalnızca iş için uygun olan en iyi adaylar belirlenerek onlarla görüşülmektedir. İK analitiği ayrıca işgücü planlaması ve optimizasyonu için de kullanılmaktadır. Örneğin simülasyon modelleri, belirli becerilere sahip çalışanların arz ve talebini, doğru zamanda doğru pozisyonda doğru sayıda çalışana sahip olmak için değerlendirebilmektedir. İş yükü veya kurumun hedefleri gibi koşullar değiştikçe işe alma ve elde tutma planlarını güncellemek için modeller yeniden tasarlanarak çalıştırılabilmektedir (Narula, 2015).

İK Analitiği yıllardır tartışılsa da gelişmekte olan bir trendi ve yeniliği temsil etmektedir. Bu nedenle, İK analitiğini yaygınlaşan bir yenilik olarak ele almak uygun görünmektedir (Marler ve Boudreau, 2017). İK analitiğinin önem kazanmasının temel nedenlerinden biri, insan kaynaklarında anlamlı iç görüler için işlenmek ve yorumlanmak üzere veriye dayalı yaklaşımların işletmecilik alanında da benimsemesidir. Yapay Zekâ, İK Analitiği için pratik anlamda mükemmel fırsatlar yaratmaktadır (Sooraksa, 2021). Bu veri analizi yöntemi, İK tarafından rutin olarak toplanan verileri almakta, sonrasında ise IKK ve kurumsal hedefler ile ilişkilendirmektedir. Böylece, İK süreçlerinin ve fonksiyonlarının kurumun hedef ve stratejilerine nasıl katkıda bulunduğuna ve kuruma ne ölçüde bir değer yarattığına ilişkin ölçülebilir kanıtlar sağlamak mümkün olabilmektedir. Örneğin, bir kurumun çalışan devir hızının yüksek olması, o kurumda yolunda gitmeyen bazı süreçler olduğuna ve verimli bir şekilde faaliyet gösteremediğine işaret etmektedir. Bunun nedenlerini saptamak ve çalışanları tamamen üretken bir düzeye çıkarmak hem zaman hem de yatırım gerektirmektedir. Bu aşamada İK analitiği, hangi sürecin iyi çalışıp çalışmadığını belirlemekte ve süreçlere ilişkin veri destekli bilgiler sağlamaktadır. IK analitiği sayesinde elde edilen veriler sayesinde, kurum sorunlu süreçlerinde iyileştirmeler yapabilmekte ve gelecek için öngörüler de bulunarak daha etkili planlar yapabilmektedir. Söz konusu örnekte olduğu gibi, kurumun yüksek işgücü devir oranının nedenini bilmek, bunun nasıl azaltılabileceğine dair değerli bilgiler sağlayabilmekte ve kuruma verimliliğini arttırmada yol gösterici olmaktadır.

İK uzmanları, birçok İK sorununa geleneksel yöntemlerle çözüm bulamamaktadır. İK analitiği sayesinde ise, kuruma stratejik değer katacak birçok soruya çözüm bulabilmekte ve böylece etkin stratejiler geliştirebilmektedir (Hamilton ve Sodeman, 2020). Örneğin, hangi eğitim programları daha fazla üretkenliğe ya da yeniliklere yol açmaktadır? Hangi ücret ve yan haklar paketleri çalışanları cezbetmekte ve elde tutmaktadır? Hangi motivasyon programları çalışanların verimliliklerini arttırmaktadır? Son iki yılda işten ayrılmaların sayısı neden artmıştır? İşe yeni başlayan çalışanlardan hangileri iki yıl içinde en yüksek performansı gösterebilir veya hangileri ilk yıl işten ayrılma niyetinde olabilir? Bu tür bilgilere sahip bir işletme, bütün işe alım süreçlerini yeniden tasarlayabilir ve bütün İK süreçlerini optimize edebilir. Ancak İK departmanlarının geleneksel yöntemler ile bu sorulara ne ölçüde cevap verebileceği tartışmalıdır. Bu soruları yanıtlamak için İK, gereken verileri yakalamalı ve bunları analiz ettikten sonra, veri analizlerinden faydalı içgörüler oluşturmalıdır. Bu şekilde bu sorunları çözebilmek mümkün olmaktadır. İK'nın veri topladığı ve bazı durumlarda geçmiş verileri analiz ettiği ve geçmişte ne olduğunu gördüğü sıklıkla gözlemlenmektedir ancak geçmiş verilere dayanarak gelecekte ne olacağını tahmin etmeye çalışmazlar (Levenson ve Fink, 2017). Tahmin edici analitik, kurumun geçmiş verilere dayanarak tahminde bulunmasına imkân vermektedir. Sürekli olarak farklı kaynaklardan veri yakalamak ve bu yüksek hacimli verileri işlemek, tahmin edici analitik oluşturmayı sağlamaktadır (Hamilton ve Sodeman, 2020). Bu tahmin edici analitik, veriler arasındaki örüntüleri ve bağlantıları yakalar ve böylece İK yöneticileri de hangi önlemlerin alınacağını ve hangi kaynakların tahsis edileceğini anlayabilmektedir (Gurusinghe, 2021). İK analitiği, insan kaynakları bilgi sisteminde tutulan bilgileri kullanmaktadır. Birbirine bağlı birçok bileşen sisteminden oluşmaktadır. Çeşitli bileşenler genel olarak veri ambarı, veri analitiği, performans yönetim sistemi ve bilgi dağıtımı olarak dört alt sistemde sınıflandırılabilmektedir (Narula, 2015).

\section{İK analitiğinde yapay zekânın yeri}

Yapay zekânın doğuşu Alan Turing'in 1950'de yayınladığı çığır açan çalışması "Computing Machinery and Intelligence" ile olmuştur. Turing çalışmasında "Makineler düşünebilir mi?" sorusunu sormuş ve bir insan sorgulayıcının; bir bilgisayar ve insan metin yanıtını ayırt etmeye çalışacağı, "Turing Testi" olarak bilinen bir test sunmuştur. Bu test, yayınlanmasından bu yana çok fazla incelemeye tabi tutulmuş olsa da dilbilim etrafındaki fikirleri kullandığından, yapay zekâ tarihinin önemli bir parçası olmuş ve felsefe içinde süre gelen bir kavram olmaya devam etmektedir.

Yapay zekâ, insan zihninin problem çözme ve karar verme yeteneklerini taklit etmek için bilgisayarlardan ve makinelerden yararlanan bir bilimdir. Son birkaç on yılda bir dizi yapay zekâ (AI) 
tanımı ortaya çıkmış olsa da McCarthy (2004) makalesinde yapay zekâyı; akıllı makineler özellikle akıllı bilgisayar programları yapma bilimi ve mühendisliği olarak tanımlamaktadır. Yapay zekâ, insan zekâsını anlamak için bilgisayar kullanmanın benzer göreviyle ilgilidir, ancak kendisini biyolojik olarak gözlemlenebilir yöntemlerle sınırlaması gerekmez. Bir diğer yapay zekâ tanımı ise "dijital bir bilgisayarın veya bilgisayar kontrollü bir robotun, genellikle akıllı varlıklarla ilişkili görevleri yerine getirme yeteneği" olarak ifade edilmektedir. Bu terim sıklıkla akıl yürütme, anlam keşfetme, genelleme yapma veya geçmiş deneyimlerden öğrenme gibi insanlara özgü entelektüel süreçlerle donatılmış sistemleri geliştirme projesine uygulanmaktadır. Russell ve Norvig (2010), bilgisayar sistemlerini rasyonalite ve düşünme ile hareket etme temelinde farklılaştıran dört potansiyel yapay zekâ hedefini incelemişlerdir.

Günümüzde yaşamın her alanında yapay zekânın etkilerini görmek mümkündür. Robotlardan, otonom araçlara, dijital kanallarda bizlere sunulan film önerilerinden, tıbbi karar destek sistemlerine, örüntü tanıma sistemlerinden yüz ifadelerinin analizine kadar birçok alanda yapay zekâ uygulamaları görülmektedir. Yapay zekâ; duygu tanıma, müşteri hizmetleri, öneri motorları, tıbbi teşhis, oyun oynama, konuşma ve ses tanıma, el yazısı tanıma, doğal dil işleme, bilgisayarlı görü, uzman sistemler, sezgisel sınıflandırma vb. gibi birçok alanda uygulamaya sahiptir. İşletmecilik alanında da yapay zekâ uygulamalarının yansımaları artan bir şekilde görülse de İK alanı halen yapay zekânın sunduğu avantajlardan ve kolaylıklardan yararlanma konusunda nispeten geride kalmaktadır. İnsan kaynakları yönetiminin stratejik ortak olma rolünün son yıllarda önem kazanması ile beraber, İK yöneticileri de artık strateji belirleme süreçlerinde yer almaktadır ve karar verme süreçlerinde insan kaynakları bilgi sistemlerinin de önemi giderek artmıştır. Rekabetçi iş ortamındaki hızlı değişimler beraberinde hızlı aksiyonlar gerektirdiğinden, işletmeler de İK sistemlerinde yeni teknolojilerin kullanılmasının gerekliliğinin farkına varmıştır. Veri odaklı karar vermenin etkinliğini fark eden İK departmanları, veri odaklı bir teknoloji olan yapay zekâ yöntemlerinden daha fazla yararlanmaya başlamışlardır. Geçmiş verilerden yararlanarak eğilimleri tahmin edebilen ve öneriler sunan yapay zekâ yöntemleri, büyük hacimdeki veri yığınını analiz etmekte ve bu verilerden anlamlı çıkarımlar yapmaktadır (Merlin ve Jayam, 2018). Yapay zekâ yöntemleri ve İK analitiği kullanmadan önce verileri manuel ve yarı otomatik bir şekilde yönetmeye çalışmakla uğraşmakta ve kısa zaman içinde bunu etkin biçimde başaramamaktaydı. Analitik oluşturmak için verileri toplamak, depolamak, işlemek ve tüm bu işlemleri kısa bir süre içinde yapmak gerekmektedir çünkü koşullar değiştikçe verilerin de güncellenmesi gerekmekte ve veriler hizla alakasız hale gelebilmektedir (Matyunina, 2020).

Yapay zekâ araçları, insan kaynakları fonksiyonlarında uygulamacılar için oldukça zaman alan süreçleri etkin bir biçimde çözecek ve böylece işgücünün hem daha üretken hem de zamandan tasarruf ederek çalışmasını sağlayacaktır. Ayrıca kurumsal hedeflere ve stratejilere uygun biçimde İK stratejileri ve süreçleri belirleme konusunda da İK yöneticilerine yol gösterici olacaktır. İK analitiği bu süreçte özellikle geçmişe dönük verilerden yararlanma imkânı sunarak, geleceğe dönük uygulamalar belirleme noktasında İK departmanlarına önemli fikirler verebilmektedir (Murgai, 2018). Yapay zekâ uygulamaları, insan kaynakları hakkında derin, eyleme dönüştürülebilir içgörüler ve tahminler ortaya çıkarmak için gelişmiş İK analitiğini desteklemektedir (Margherita, 2020).

\section{İK analitiği ve işe alım}

Personel seçme ve yerleştirme süreci, işletmenin hedefleri ve stratejileri doğrultusunda etkin olarak yürütülmesi gereken en maliyetli ve zorlu süreçler arasında görülmektedir. İş gereklerine uygun beceri ve yetkinlikte adayların, doğru pozisyon ile doğru zamanda eşleştirilmesi her zaman geleneksel işe alım yöntemleri ile mümkün olamamaktadır. Bu durum insanların özelliklerini kısa süre içinde tanımanın verdiği zorluktan ve kimi zamanda karar vericilerin işe alım süreçlerinde ve özellikle mülakatlarda yaptıkları hatalardan kaynaklanmaktadır. Yanlış verilen kararlar ve tercihler sonucunda hem çalışan işinde mutsuz olmakta hem de işletme çalışandan istediği verimi alamamaktadır. İş gereklerine uygun olmayan adayların seçilmesi ve işe yerleştirilmesi sonucunda yaptığı işten motive olmayan ve iş tatmini düşen çalışan işten ayrıldığı zamansa, işletmede uzun vadede işgücü devir oranlarını yükselmekte ve bu durum ciddi bir zaman ve maliyet kaybı yaratmaktadır.

İşe alma süreci; ilana çıkma, aday arama, adaylarla görüşme, testler, değerlendirmeler, işe başlama süresi ve oryantasyon vb. birçok maliyeti içermektedir. Bu maliyetler kimi zaman çalışanın yıllık maaşının ortalama bir ile dört katına kadar çıkabilmektedir. Ancak yanlış kişi işe alındığında ise, yanlış bir işe alımın kuruma maliyeti çalışanın yıllık maaşının beş katına kadar çıkabilmektedir (VanVulpen, 2019). İşe alım mülakatları kimi zaman mülakatçıların hatalarından veya diğer sübjektif faktörlerden olumsuz yönde etkilenebilmekte ve karar vericiler bu süreçte zaman zaman yanlı tercihler yapabilmektedir. İşe alım sürecinde kullanılan yapay zekâ yöntemleri sayesinde, İK uzmanlarının işi kolaylaşmakta ve iş gereklerine uygun olan adayları saptamada daha doğru 
eşleştirmeler yapmalarına imkân vermektedir. Nihai karar vericinin yine insan olduğu bu sistemler, vericilere yol göstermekte ve zamandan tasarruf sağlayarak etkin karar verilmesine yardımcı olmaktadır. Zamanlarının büyük çoğunluğunu adayları seçmek ve mülakat yapmak için harcayan İK uzmanları, yapay zekâ sistemlerinin yardımı ile potansiyel adayları kısa sürede daha verimli bir şekilde belirleyebilmektedir (Murgai, 2018). Açılan pozisyonlara kimi zaman onlarca veya yüzlerce adayın başvurabildiği düşünüldüğünde, işe alım sürecinin ilk aşaması olan özgeçmişlerin incelenmesi için bile ciddi bir zaman ve emek harcanması gerekmektedir. Bu aşamada yapay zekâ, işe alım sürecinde rutin ve zaman alıcı işleri kolaylaştırmaktadır. Yapay zekâ tarafından desteklenen akıllı tarama yazılımı, çalışanların deneyimini ve becerilerini inceleyerek, pozisyonun iş gereklerine uygunluğunu saptamakta ve en uygun görünen adayların listesini verebilmektedir (Ahmed, 2018). Yüzlerce özgeçmişi saniyeler içinde tarayabilen sistemler, uygulamacılara ciddi bir zaman tasarrufu sağlamakta ve iş gerekleri ile aday niteliklerini en uygun şekilde eşleştirerek uygun adayları çok kısa sürede belirleyebilmektedir.

İşletmeler günümüzde işe alım süreçlerinde doğru adayları belirleyebilmek ve işe alabilmek için yüksek bütçeli değerlendirmeler, testler, simülasyonlar gibi seçme yöntemleri kullanmakta ancak çoğu işletme hala adaylarının büyük kısmının yanlış karar olduğunu belirtmektedir (Pağda, 2018; Ahmed, 2018). Bu kadar yüksek oranda harcamalara rağmen, yöneticilerin birçoğu değerlendirmeye ilişkin son kararı yine kendi sezgileri veya önyargılarına göre vermektedirler. Araştırmalar işe alım yöneticilerinin birçoğunun bir adayla buluştuğu ilk dakikada, genellikle bakış, el sıkışma, kıyafet ve konuşma gibi özelliklere dayanarak bir aday hakkında hemen karar verdiğini göstermektedir (Murgai, 2018). Faliagka, Illiadis, Karydis, Rigou, Sioutas, Tsakalidis ve Tzimas (2014) çalışması aday başvurularına ilişkin sorunları çözmek için yapay zekâda makine öğrenme algoritmalarının kullanımından bahsetmektedir. Önerilen sistem, İK analitiği yoluyla başvuran adayların Linkedin profilinden bir dizi nesnel ölçüt çıkarmakta ve bunları anlamsal olarak pozisyonun iş gerekleri ile karşılaştırmaktadır. Ayrıca adayların başvurularındaki ifadelerini dilbilimi analizi ile incelemekte ve kişilik özelliklerine ilişkin profil belirlemektedir. Böylece İK uygulamacıları geniş bir aday havuzu içinden uygun adayları düşük bir maliyetle ve zamandan tasarruf ederek hedefleyebilmektedir (Faliagka vd., 2014). İK analitiğinin işe alım sürecinde kullanılması ile olası en uygun adayı belirlemek için yüzlerce veya binlerce özgeçmiş hızlıca taranabilmekte, adayın işe alınma durumunda olası performansı tahmin edilebilmekte ve İK uzmanlarının adaylarla direkt olarak iletişim kurma gerekliliği ortadan kalkmaktadır (Matyunina, 2020).

\section{İK analitiği ile işgücü devir oranını azaltma ve işten ayrılma niyetinde olan çalışanları belirleme}

Çalışanların işten ayrılma niyetini ve işgücü devir oranını etkileyen birçok farklı faktör bulunmaktadır. Bu faktörlerin neler olabileceği 1930'lu yıllardan beri araştırılmaktadır. İşgücü devrine etki eden yaş, eğitim, cinsiyeti kıdem vb. gibi ilk akla gelen faktörler olabileceği gibi işe olan mesafe, evli veya bekar olma durumu, seyahat etme zorunluluğu gibi çeşitli faktörler de sayılabilmektedir. İK analitiğinin görevlerinden biri de bu faktörleri ortaya çıkarmak ve işgücü devir oranına etkilerini belirlemektir. İşgücü devir oranının artması işletmelere ciddi bir maliyet ve zaman kaybı getirmektedir. CEO'lar genellikle, çalışanların doğum günleri veya İK performansını optimize etme gibi konularla pek ilgilenmez ancak kurumun doğru insanlara sahip olup olmadığı konusunda emin olmak istemektedirler. Özellikle kurumun karlılık performansını olumsuz yönde etkilemeye başladığı zaman işgücü devir oranı maliyetinden ve bu maliyetlerin nasıl düşürüleceği konularından endişe duymaya başlamaktadırlar. Bu konular ülke ve kurumlara göre farklılık göstermektedir. Kamu kurumları çalışanların devamsızlık maliyetleri ile daha fazla mücadele ederken, özel kurumlar ise çoğunlukla yüksek işgücü devir oranları ile daha fazla mücadele etmektedir. Çalışanları değiştirmenin maliyetlerini araştıran Linkedin'in bulgularına göre, işgücü devir oranındaki \%1'lik bir azalma, 10.000 çalışanı olan bir ABD şirketine yılda yaklaşık 7,5 milyon dolar tasarruf ettirmektedir. Bu da en basit açıklaması ile bir çalışanın şirkette daha uzun süre kaldığı her ay için 750 dolar tasarruf ettiği anlamına gelmektedir. Bu nedenle işgücü devir oranı analitiği hem ABD hem de Avrupa'daki birçok işletmede İK analitiği için bir başlangıç noktası olmaktadır (Van Vulpen, 2019).

İK analitiğinde kullanılan yapay zekâ yöntemleri işten ayrılma niyetinde olan çalışanları tespit etmede önemli sonuçlar vermektedir. Daha önce istifa etmiş olan çalışanların bağlllık düzeyleri, çalışma saatleri, performans verileri ve işten ayrılmalarını ardındaki nedenlerle ilgili verileri inceleyen ve aralarındaki bağlantıları bulan sistem, işten ayrılma niyetinde olan bir çalışanı rahatlıkla tahmin edebilmektedir. İşten ayrılma niyetinde olan çalışanların belirlenmesi, özellikle yetenekli ve kilit çalışanlar söz konusu olduğunda yöneticilere bu kişilerle görüşerek sorunu önceden çözebilme imkânı vermektedir. Geleneksel İK süreçlerinde çalışanlar işten ayrılırken onlarla yapılan mülakatlar, 
çalışan kaybedildikten sonra sorunu tespit etme ve çözme olanağı sunarken, yapay zekâ sayesinde bu durum önceden tahmin edilebilmekte ve adayın istifa etme olasılığının önüne geçilebilmektedir.

Kurumun hedeflerine ulaşabilmesi için yetenekli ve kilit öneme sahip çalışanların elde tutulması çok önemlidir. Yüksek performans gösteren yetenekli çalışanlar istifa ederse, organizasyonun hayatta kalması ve rekabet avantajını koruması zorlaşmaktadır. İşletmeden ayrılma olasılığı olan çalışanların tahmin edilmesi aynı zamanda performansı yüksek çalışanları elde tutma stratejileri geliştirme açısından da büyük önem taşımaktadır. Yapay zekâ sistemlerinde kullanılan yapay sinir ağları hangi çalışanların ayrılma olasılığının bulunduğunu göstermekle beraber işgücü devrini etkileyen bilinmeyen faktörleri de ortaya çıkarabilmektedir (Strohmeier ve Piazza, 2015). Personelin işe alınması ve elde tutulması, çalışanların performans koşullarını sağlamada önemli bir rol oynadığından, organizasyonun ne kadar iyi performans gösterdiğini belirlemek için bireyin değerlendirilmesi ve örgüte bağlılığının sağlanması esastır. İK analitiği ve yapay zekâ yöntemleri bu konuda da İK uygulamacılarına yol gösterici bilgiler sağlamaktadır (Sooraksa, 2021). Böylece IKK uygulamacıları çalışan bağlılığını sağlama ve yetenekli çalışanları elde tutma konuşlarında strateji geliştirirken, elde ettikleri bu bilgilerden yararlanabilmektedir.

\section{İK analitiği ve performans değerleme}

İK analitiğinin sıklıkla kullanıldığı alanlardan biri de performans değerlemedir. Sağlanan bilginin zamanı ve kalitesi, İK karar verme sürecinin hızını ve kalitesini belirlediğinden, işletmeler tarafsız, doğru ve zamanında performans bilgilerine ihtiyaç duymaktadır. Performans değerlemeden elde edilen sonuçlar İK planlama, kariyer planlama, eğitim ve geliştirme, ücret yönetimi gibi birçok İK fonksiyonuna veri sağlamaktadır. Performans değerleme sürecinde karşılaşılan en temel sorunlardan biri bu süreçte yapılan hatalar ve önyargılardır. İK analitiği, çalışanların performans değerlemeleri ile ilgili daha nesnel, doğru ve tarafsız veriler sağlayarak sisteminin algılanan doğruluğunu ve adilliğini artırmaya yardımcı olmaktadır (Sharma ve Sharma, 2016).

Ayrıca İK analitiği sayesinde, çalışan başına elde edilen gelir, çalışan başına katkı ve insan sermayesinin getirisi gibi sektör standartları kullanılarak İK'nın genel performansı ve çalışan performansını değerlendirilmekte, böylece kıyaslamalar yapmak mümkün olabilmektedir. İK analitiği ile kurumdaki yüksek ve düşük performans gösteren çalışanlar belirlenerek, kurum içi yetenekli çalışanlar tespit edilebilmektedir. Sonrasında ise bu yeteneklerin ölçümü ve yetenek yönetimi analitiği yapılarak, elde edilen bilgiler aynı zamanda İK planlama ve kariyer planlama süreçlerinde de kullanılabilmektedir (Narula, 2015).

\section{İK analitiği ve eğitim-geliştirme}

İK analitiği ve yapay zekâ, çalışanların eğitim ihtiyaçlarının belirlenmesinde ve işletmenin stratejik ihtiyaçlarına cevap veren eğitim programları hazırlanmasına da hizmet eder. Sürekli öğrenmenin benimsendiği günümüzde çalışanların eğitim ihtiyaçlarının belirlenmesinde kullanılan geleneksel yöntemlerin yerini yapay zekâ almaktadır. Yapay zekâ günlük olarak çalışanların eğitim ihtiyaçlarını takip ederken aynı zamanda çalışanlardan aldığı geri dönüşlerle bireysel bazda eğitim programlarında iyileştirmeler yapmaktadır. Yöneticiler de yapay zekâ tarafından otomatik olarak oluşturulan ve eğitim sonuçlarını içeren raporlara ulaşmalarıyla, çalışanlarının ilerlemelerini gözlemleyebilmektedirler. Ayrıca yapay zekâ çalışanların eğitim süreçlerini iyileştirmekle kalmaz, çalışanlara süreçte yaşadıkları problemleri çözmede de asistanlık görevi yapmaktadırlar (Jia, Guo, Li, Li ve Chen, 2018).

IKK fonksiyonlarının etkin bir şekilde tasarlanması ve işletmelere değer yaratabilmesi için mevcut verilerden çıkarımlar yaparak, gelecek ile ilgili öngörüler yapmaya ve strateji belirlemeye imkân tanıyan İK analitiği her geçen gün işletmeler tarafından daha fazla kabul görmektedir. Özellikle yapay zekânın gelişimi ile beraber bu alana olan ihtiyaç ve talebin daha fazla artış göstereceği aşikardır. İK analitiği gerek teorik çerçevede yapılan çalışmalarda gerekse uygulama alanında önemi hızla artan bir konu haline gelmiştir.

\section{İK analitiği ve ücret yönetimi}

Çalışanlara sunulan ücret paketlerinin içeriğinin ve yan hakların belirlenmesi işletmeleri ücret yönetimi sistemi içinde en çok zorlayan konulardan biridir. Ücret çalışanı motive etme anlamında her ne kadar hijyen faktör olarak görülse de yetenekli çalışanları işletmeye cezbetme, elde tutma, iş tatmini sağlama konularında ne denli önemli olduğu tartışılmazdır. Çalışanlara sunulan esnek yan haklar ve ücret paketlerinin motivasyonu sağlamada önemli rolü bulunmaktadır. İK analitiğinin kullanımı sayesinde, kurumun hedeflerini strateji ile uyumlu hale getirmek, ücretleme ve performans 
arasındaki bağlantıyı anlamak, adil ve tutarlı ücret sağlamak ve değişken ücretleri kurumun hedef ve stratejileri ile entegre etmek mümkün olabilmektedir (Narula, 2015).

\section{İK analitiği ve İK planlama}

Yapay zekâ tabanlı İK analitiği algoritmaları, insanların sosyal medyadaki ve diğer kamuya açık veri kaynaklarındaki ifadeleri, ruh hali değişiklikleri ve niyetlerini bir araya getirip kapsamlı bir şekilde analiz etmekte ve bunları diğer verilerle karşılaştırmaktadır. İnsan davranışı otonom öğrenen makineler tarafından simüle edilebilmektedir. Veriler doğru bir şekilde analiz edilirse, hangi çalışanların ne işle meşgul olduğu, hangi işlerde zorlandığı veya zorlanmadığ gibi süreçler hakkında bilgi sağlamaktadır. Elde edilen bu bilgiler de stratejik işgücü planlamasına yeni bir boyut kazandırmakta ve aynı zamanda çalışanların yıpranmasını azaltmaya yardımcı olmaktadır (Pwc, 2017).

\section{İK alanında yapay zekâ, makine öğrenme ve derin öğrenmenin kullanımı}

\section{Makine öğrenme}

İşletmeler sürekli olarak büyüdükçe ve daha karmaşık hale geldikçe, makine öğrenme, İK departmanlarından beklentilerdeki değişikliği yönetmeye yardımcı olmaktadır. İnsan kaynakları yönetimi uygun adayları belirleme, işe alma ve çalışanları elde tutma için strateji oluşturabilecek bir konumda olmalıdır. Çalışanları yönetebilmek için, çalışanların tutumları ve duygularını anlamak, kurum hedef ve politikalarına yönelik çalışan davranışı oluşturmak, ücret yönetimi ve ilgili dış çevre faktörlerinin ele alınması gibi birçok alanda veri toplamak gerekmektedir. Bu aşamada makine öğrenme devreye girmektedir. Makine öğrenme, bu muazzam veri hacimlerini etkin bir şekilde kabul edebilmekte, depolayabilmekte, işleyebilmekte ve yönetebilmektedir. Yapay zekâ, makine öğrenme ve derin öğrenme arasındaki ilişki aşağıda Şekil 2'de gösterilmektedir.

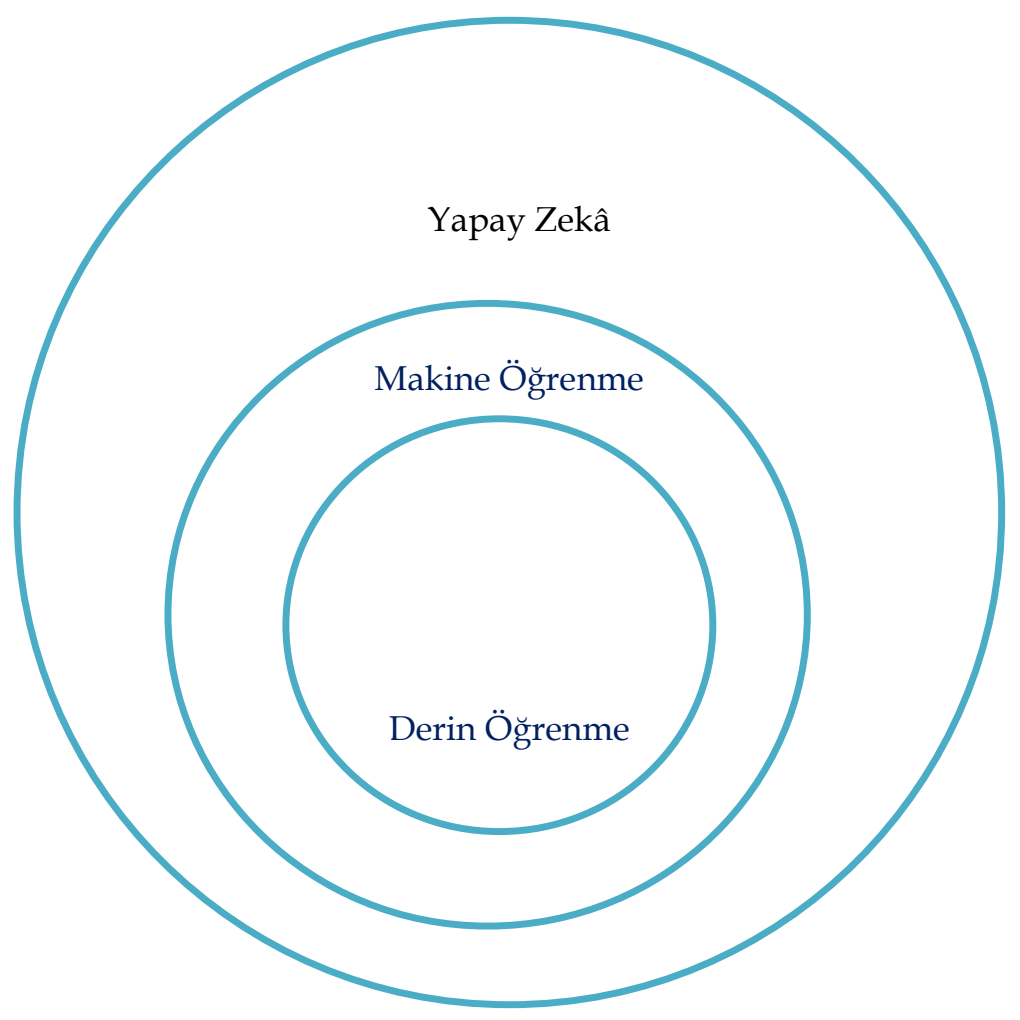

Şekil 2. Yapay Zekâ, Makine Öğrenme ve Derin Öğrenme İlişkisi

Kaynak: Yazarlar tarafından üretilmiştir.

Makine öğrenmenin İK alanında uygulamalarına bakıldığında, öncelikle daha akıllı aday tanımlama ve aday takibi görülmektedir. İşe alım modellerini belirlemek ve tanımlamak için makine öğrenme kullanılabilmektedir. Makine öğrenme ayrıca temel hareketleri ve bunların etkilerini tahmin etmeye yardımcı olabilmektedir. Makine öğrenme yoluyla, İK ekipleri olası senaryoları haritalandıran net parametreler belirleyebilmekte ve bir çalışanın kurumdan ayrılmaya ne kadar hazır olduğunu değerlendirebilmektedir. Makine öğrenme, bu gibi durumları tahmin ederek İK ekiplerine yol 
göstermekte ve proaktif bir yaklaşımla çalışanların işten ayrılma olasılığını azaltmasına yardımcı olmaktadır.

İşe alım sürecinde, blog ve sosyal medya profillerini analiz etmek ve özgeçmişte görünmeyen aday özelliklerini belirlemek için makine öğrenme kullanılabilmektedir (Matyunina, 2020). Makine öğrenmenin İK alanındaki diğer bir uygulama konusu ise çalışan başarısını tahmin edebilmektir. Bir adayın kimlik bilgilerine, tutumlarına, üyeliklerine ve performansına ilişkin veriler, genellikle bir pozisyondaki olası başarısına etkili bir şekilde işaret edebilmektedir. Makine öğrenme bu aşamada, kurumdaki en başarılı çalışanlarla ilgili geçmiş verilere erişim verildiğinde İK ekibine yardımcı olabilmektedir. Örneğin; İK ekibi kurumdaki en başarılı ilk 10 çalışanı belirleyip bilgilerini ve geçmiş verilerini sisteme aktardığında, sistem makine öğrenme yoluyla bu çalışanların eğitim nitelikleri, genel tutumları, kurumun öğrenme ve gelişim programına duyarlılıkları ve kariyer yolunda ilerlemelerine kadar çalışan başarısı ile ilişkili olabilecek farklı parametreleri tanımlayabilmektedir. Makine öğrenme etkin program, sonrasında bu verileri kurum için potansiyel adayların mevcut parametreleri ile eşleştirebilmekte ve tahmini yeteneklerle işe alınan personelin hangi pozisyonda başarılı olabileceğini ortaya çıkarabilmektedir. Bu nedenle, makine öğrenme yoluyla elde edilen İK analitiği, kurumun işe alım stratejileri geliştirmesinde ve işe alım kararlarına rehberlik etmesinde çok önemli bir yardımcı olabilmektedir (Writer, 2018).

Makine öğrenmenin İK alanında bir diğer kullanımı ise adaylarla yapılan mülakatların değerlendirilmesidir. Makine öğrenme tarafından analiz edilen video tabanlı görüşme, adayın doğruyu söyleyip söylemediğini ve görüşülen kişinin ruh halini belirlemeye yardımcı olabilmektedir. Görüşme kaydedilmekte ve kas kasılmaları, ses tonu vb. kriterlerle analiz edilmesi için sinir ağına verilmektedir. Örneğin, bir adayın önceki işinden bahsederken kaşlarını çatması olumsuzluk belirtisi olabilmektedir. Ses tonu ise, adayın bu kurumda çalışma isteğini, sorumluluklarındaki hevesini veya kayıtsızlı̆̆ını gösterebilmektedir. Makine öğrenme bir adayın cinsiyeti veya yaşı ile ilgilenmez, yargılamaz veya eleştirmez, kötü bir gün geçirip, olumsuz tavrını adaya yansıtmaz. Tamamen tarafsız ve önyargıdan uzak bir biçimde olarak adayı değerlendirmektedir (Matyunina, 2020). Makine öğrenmenin hangi İK süreçlerinde ve fonksiyonlarında kullanıldığı Şekil 3’de gösterilmektedir.

Ayrilma / Emeklilik Yer değiştirme Emeklilik yönetimi Yeni mezun ve eski çalışan havuzu

Uyum ve Raporlama Önyargıları gözleme Çalışan faaliyetlerinin denetimi

Risk Yönetimi

Elde tutma ve yıpranma analitiği Devamsızlık ve iş kazası tahmini Dolandırıcılık tespiti

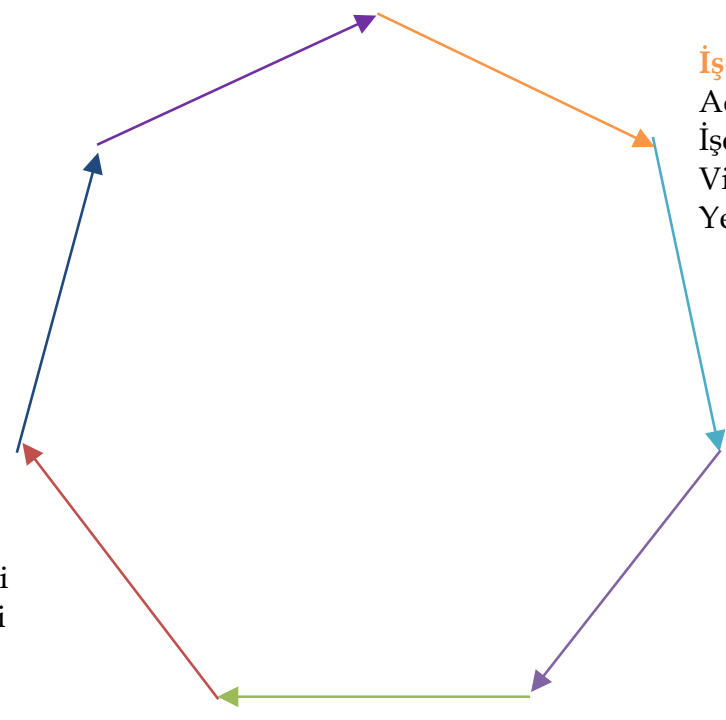

Çalışan Bağlılığı ve Tanınma Ücret ve yan haklar otomasyonu Çalışan bağlılığı takibi
İşe Alım Havuzu

Aday havuzu

İşe alım süreci otomasyonu

Video mülakatlar

Yeni çalışanların performans tahmini

Eğitim ve Geliştirme

Oryantasyon

Referans bilgisi

Kişisel koçluk
Performans Yönetimi

Hedef belirleme

Potansiyel tahmini

Performans tahmini

Takım uyumu psikometrisi

Şekil 3: Makine Öğrenmenin İK ve İşe Alım Süreçlerinde Kullanımı

Kaynak: Matyunina, 2020 
Linkedin de işe alım sürecinde aday aramaları sınırlamak ve akıllı algoritmaların yardımıyla aday aramak için İK analitiğinden ve makine öğrenme yöntemlerinden yararlanmaktadır. Google tarafından geliştirilen makine öğrenme araçları olası adayların özelliklerini analiz edebilmekte ve daha sonra onlara becerilerine, deneyimlerine ve kişiliklerine uygun iş pozisyonlarını kendilerine sunabilmektedir. Bu yöntem sayesinde özellikle kurumun hedeflerine ve stratejilerine uygun yetenekli adaylar bulmak mümkün olabilmektedir. Makine öğrenme ayrıca, İK personeline anında geri bildirim toplayıp paylaşabilen mobil uyumlu araçlar sağlamaktadır. Çalışan anketlerinde öne çıkan konuları ve yinelenen sorunları belirlemek için makine öğrenme uygulamak, geri bildirim kalitesini artırmaya yardımcı olabilmekte ve İK politikalarını belirlemede yol gösterici olmaktadır (Matyunina, 2020).

Makine öğrenme; denetimli öğrenme, denetimsiz öğrenme ve pekiştirmeli öğrenme olarak üç yönteme ayrılmaktadır. Bu yöntemlerden aşağıda bahsedilmektedir:

\section{Denetimli öğrenme}

Makine öğrenme içinde denetimli öğrenme yöntemleri, girdi öznitelikleri ve bir hedef öznitelik arasındaki ilişkiyi keşfetmeye yarayan yöntemlerdir. Keşfedilen ilişki, model olarak adlandırılan bir yapıda temsil edilmektedir. Genellikle modeller, veri kümesinde gizli olan ve girdi özniteliklerinin değerlerini bilerek hedef özniteliğin değerini tahmin etmek için kullanılabilen olayları tanımlamakta ve açıklamaktadır. Denetimli öğrenmenin iki türü bulunmaktadır. Bunlardan biri, sınıflandırma modelleri (sınıflandırıcılar) ve diğeri de regresyon modelleridir. Sınıflandırıcıları temsil etmek için kullanılan birçok alternatif vardır. Örneğin; karar ağaçları, destek vektör makineleri, cebirsel fonksiyonlar, olasılıksal yöntemler, vb. denetimli yöntemler, insan kaynakları, üretim, finans, pazarlama vb. çeşitli alanlarda uygulanabilmektedir (Maimon ve Rokach, 2010).

İK alanında en yaygın makine öğrenme yöntemleri, denetimli öğrenme ve ardından denetimsiz öğrenme yöntemleridir. Denetimli öğrenme yöntemi ile bir çalışanın kurumdan ayrılıp ayrılmayacağı, yeni bir çalışanın ideal başlangıç maaşının ne olması gerektiği gibi bir sonucu tahmin etmek mümkün olabilmektedir. Tahmin yapmak için farklı girdi değişkenlerine (özelliklerine) ihtiyaç bulunmaktadır. Girdi özellikleri; önemli olacağı düşünülen durumlarla, hangi verilerin kullanılabileceğiyle veya hangi verilerin oluşturulabileceğiyle sınırlıdır.

\section{Denetimsiz öğrenme}

Bir sonucun tahmin edilmeye çalışıldığı denetimli öğrenmenin aksine, denetimsiz öğrenme (denetimsiz makine öğrenme olarak da bilinir), verilerdeki benzerlikleri, farklılıkları, gizli örüntüleri, veri gruplarını veya ilişkileri belirlemek için birçok değişkeni aynı anda analiz etmektedir. Denetimsiz öğrenme, etiketlenmemiş veri kümelerini analiz etmek ve kümelemek için makine öğrenme algoritmalarını kullanmakta ve verilerde ne olduğunu anlamakla ilgilidir. Bu algoritmalar insan müdahalesi olmadan işlemleri gerçekleştirebilmektedir. Bilgilerdeki benzerlikleri ve farklılıkları keşfetme yeteneği, denetimsiz öğrenme yöntemini keşifsel veri analizi, çapraz satış stratejileri, müşteri segmentasyonu ve görüntü tanıma için ideal çözüm haline getirmektedir.

Denetimsiz öğrenmenin en yaygın iki kullanım yöntemi kümeleme ve birliktelik kural madenciliğidir. Kümeleme; etiketlenmemiş verileri benzerliklerine veya farklılıklarına göre otomatik olarak gruplayan bir veri madenciliği tekniğidir. Kümeleme algoritmaları; ham, sınıflandırılmamış veri nesnelerini, bilgilerdeki yapılar veya örüntülerle temsil edilen gruplar halinde işlemek için kullanılmaktadır. Kümeleme algoritmaları, özellikle örtüşen, hiyerarşik ve olasılıksal olmak üzere birkaç türe ayrılabilmektedir. Kümeleme de en yaygın kullanılan algoritma, K-ortalama Kümeleme algoritmasıdır. Bu algoritma, sürekli olarak kümelerin yenilendiği ve en uygun çözüme ulaşana kadar devam eden döngüsel bir algoritmadır.

Kümelemenin İK alanındaki uygulamalarında, kurumun çalışan segmentlerini (yani kümelerini) anlamak ve İK politikalarının bu segmentlere uygun olup olmadığı belirlemek ön plana çıkmaktadır. İnsan kaynakları alanında kullanılan kümeleme analizinde ulaşılmak istenilen diğer bir hedef ise kurumun verilerinden çalışan devri ile ilişkili faktörlerin anlaşılmasıdır. Yang ve Islam (2020) çalışmalarında, çalışanların istifa etmeyi seçmelerinin ana nedenlerini bulmak için "IBM Çalışan Yıpranma" veri kümesini analiz etmişlerdir. Bunu yapmak için yaş, medeni durum, pozisyon düzeyi vb. gibi bir dizi çalışan değişkenine (yani öznitelikler) dayalı kümeler oluşturmuşlardır. Kümeler, işgücü devri ile ilişkilendirilebilecek birçok özniteliği ve işten ayrılmaya daha duyarlı farklı çalışan kümeleri olup olmadığını daha iyi anlamaya yardımcı olmaktadır. Bu son iç görü, mevcut İK politikalarının her koşula uyan tek bir yaklaşım kullanmak yerine analizde belirlenen çalışan kümelerine hizmet edip etmediğini belirleyerek çalışan deneyiminin geniş ölçekte kişiselleştirilmesini kolaylaştırabilmektedir. 
Denetimsiz öğrenmenin bir diğer yöntemi ise birliktelik kuralı madenciliğidir. Bu yöntem, belirli bir veri kümesindeki değişkenler arasındaki ilişkileri bulmak için kural tabanlı olarak çalışmaktadır ve sıklıkla birlikte oluşan değişken kümelerini tanımlamaktadır. Bu yöntemler, özellikle pazar sepeti analizi için sıklıkla kullanılmakta ve kurumların farklı ürünler arasındaki ilişkileri daha iyi anlamalarını sağlamaktadır. Böylece müşterilerin tüketim alışkanlıklarını anlamak, işletmelerin daha iyi çapraz satış stratejileri ve öneri motorları geliştirmesine imkân vermektedir.

Birliktelik kurallarını oluşturmak için kullanılan Apriori, Eclat ve FP-Growth birkaç farklı algoritma olsa da en yaygın olarak Apriori algoritması kullanılır. Apriori algoritması (Agrawal ve Srikant, 1994) sık öğe küme madenciliği ve birliktelik kuralı öğrenme için bir algoritmadır. Girmanova ve Gasparova (2018), çalışmalarında, veri madenciliğine dayalı birliktelik kuralları ve karar ağaçları kullanarak işgücü devrine ilişkin verileri analiz etmişler ve değerlendirme sonuçlarını sunmuşlardır.

Birliktelik kuralları madenciliği; işe alım, kariyer yolları, eğitim ve yetenek yönetimi gibi İK uygulamalarındaki örüntüleri belirlemek ve daha sonra hangi örüntülerin mutlu ve üretken çalışanlarla ilişkili olduğunu belirlemek için kullanılabilmekte ve sonrasında özelleştirilmiş içerik oluşturmak için İK sistemine geri bildirim sağlama imkânı vermektedir.

\section{Pekiştirmeli öğrenme}

Pekiştirmeli öğrenme yöntemi, ortamını algılayan ve hareket eden otonom bir etmenin hedeflerine ulaşmak için en uygun eylemleri seçmeyi nasıl öğrenebileceği sorusunu ele almaktadır. Bu öğrenme türü, bir algoritmanın kendi eylemlerinden ve deneyimlerinden gelen geri bildirimleri kullanarak deneme yanılma yolu ile öğrenmesini sağlayan bir yöntemdir. Bu yöntem, bir mobil robotu kontrol etmeyi öğrenmek, fabrikalardaki operasyonları optimize etmeyi öğrenmek ve tahta oyunları oynamayı öğrenmek gibi oldukça genel bir problemi ve görevleri kapsamaktadır. Etmen kendi ortamında bir eylemi gerçekleştirdiğinde, bir eğitmen ortaya çıkan durumun istenildiğini belirtmek için bir ödül veya ceza verebilmekte ve sonuçta bu algoritmayı süreçte daha akıllı hale getirmektedir. Örneğin, bir etmeni bir oyunu oynaması için eğitirken, eğitmen oyun kazanıldığında pozitif bir ödül, kaybedildiğinde, negatif bir ödül ve diğer tüm durumlarda sıfır ödül sağlayabilmektedir. Etmenin görevi, bu dolaylı gecikmiş ödülden öğrenmek, en büyük birikimli ödülü üreten eylem dizilerini seçmektir. Pekiştirmeli öğrenme algoritmaları, optimizasyon problemlerini çözmek için sıklıkla kullanılan dinamik programlama algoritmaları ile ilgilidir (Mitchell, 1997).

Pekiştirmeli öğrenme örnekleri; finans ve yatırım alanında gelişmiş tahminler yapma, tedarik zinciri işlemlerinde bir depodaki siparişleri yerine getiren robotlar, trafik akışı optimizasyonu ve sağlık hizmetlerinde biyopsi görüntülerinin incelenmesi gibi alanlarda yaygın olarak kullanılmaktadır. IK alanında pekiştirmeli öğrenme yöntemlerinin kullanımı daha düşük düzeyde de olsa, özellikle eğitim gibi alanlarda çalışanın performans artışına ve ilerlemesine göre içerik uygulama konusunda kullanılmaktadır. Majd, Mahootchi ve Zakery (2017) çalışmasında insan kaynağının kritik bir rol oynadığı yüksek teknolojili bir endüstri için insan kaynakları planlaması ve üretim-envanter kontrolünün birleşik bir problemini ele almaktadır. Çalışmalarında, talep belirsizliği altında işçileri işe almak için en uygun kararı elde etmek amacıyla bir pekiştirmeli öğrenme (RL) modeli önermişlerdir. Önermiş oldukları modele ayrıca, işten çıkarma ve fazla mesai saatleri gibi bazı yönetsel konuları da dahil etmişlerdir. Cheng (2020) çalışmasında ise çalışan iş gücü devir oranının çok katmanlı bir algılayıcı tahmin modelini oluşturmuştur. Çalışan devir oranını azaltmak için otomatik olarak bir dizi strateji oluşturmak amacıyla bir tür pekiştirmeli öğrenme algoritması olan Sarsa'ya dayalı bir model önermişlerdir. Bu stratejiler, işletme açısından işgücü devir oranını en yüksek düzeyde ve maliyeti daha az düzeyde azaltabilecek stratejiler bütünüdür ve işletmenin çalışan sistemini optimize etmesi için bir referans plan olarak kullanılabilmektedir. Deneysel sonuçlar, algoritmanın belirli stratejinin verimliliğini ve doğruluğunu gerçekten iyileştirebileceğini göstermektedir.

\section{Yapay sinir ağları}

Yapay sinir ağları kavramı insan beyninin çalışma prensiplerinin dijital bilgisayarlar üzerinde taklit edilmesi fikri ile ortaya çıkmış ve ilk çalışmalar beyni oluşturan nöronların (yani, biyolojik hücrelerin), matematiksel olarak modellenmesi üzerinde yoğunlaşmıştır. Bu çalışmaların ortaya çıkardığı bulgular, her bir nöronun komşu nöronlardan bazı bilgiler aldığı ve bu bilgilerin biyolojik nöron dinamiğinin öngördüğgü biçimde bir çıktıya dönüştürüldüğü şeklindeydi. Yapay sinir ağları olarak adlandırılan alan, birçok nöronun belirli biçimlerde bir araya getirilip bir fonksiyonun gerçeklenmesi üzerindeki yapısal olduğu kadar matematiksel ve felsefi problemlere yanıt arayan bir bilim dalıdır. Yapay Sinir ağları yapısının çözebileceği problem uzayı, insan beyninin çözebildiği problem uzayının oldukça kısıtlanmış bir alt kümesidir (Efe ve Kaynak, 2000). 


\section{Karar ağaçları}

Karar ağaçları (Quinlan, 1986), böl ve yönet yaklaşımını gerçekleyen ağaç yapılı bir veri yapısıdır. Dağglıma bağlı tahminde, tüm girdi uzayında geçerli bir model varsayar ve parametreleri tüm veriyi kullanmak suretiyle öğrenilir. Ardından her deneme girdisi için aynı yapı ve parametre kümesi kullanılır. Dağılımdan bağımsız tahminde, Eucklid (Öklid) uzaklığı gibi bir kriterle girdi uzayını yerel parçalara ayırır ve her girdi için kendi bölgesindeki veriyle eğitilmiş bir yerel (lokal) model kullanılır. Karar ağacı, denetimli öğrenme için kullanılır. İlgili yerel bölgenin öz çağrılı bir biçimde, bir dizi bölmeyle az sayıda adımda bulunduğu ağaç yapılı bir modeldir. Karar ağacı, iç karar düğümleri ve uç yapraklardan oluşur. Karar ağacı, dağılımdan bağımsızdır çünkü sınıf dağılımlarıyla ilgili bir varsayım yapmaz; ağaç yapısı baştan sabit değildir, verinin altında yatan fonksiyonun karmaşıklığına göre dallar ve yapraklar eklenerek ağaç büyür. Her yaprağın bir çıktı değeri vardır ki, bu sınıflandırmada bir sınıf etiketi, bağlanımdaysa sayısal bir değerdir. Her yaprak, girdi uzayında bir alan tanımlar ve bu alana düşen tüm örneklerin sınıflandırmada aynı etiketi, bağlanımdaysa benzer sayısal çıktısı vardır. Alanların sınırları kökten yaprağa inen yol üstündeki iç karar düğümlerince tanımlanır. Kararların bir ağaç yapısı oluşturması girdiyi kapsayan alanın hızla bulunmasını sağlar. Karar ağaçlarının bir başka üstünlüğü yorumlanabilirliktir. Bir karar ağacı, kolayca anlaşılabilen bir küme EĞER-İSE kuralı olarak yazılabilir. Bu yüzden karar ağaçları, yaygın olarak kullanılır ve bazen daha başarılı, ama daha zor olarak yorumlanan yöntemlere tercih edilir. Karar ağacı öğrenmek, bir öğrenme kümesi verildiğinde bir ağaç oluşturmak demektir. Bir öğrenme kümesini öğrenen birden çok ağaç olabilir ve basitlik için bu ağaçların en küçüğgu bulunmak istenir. Bir ağacın büyüklüğü, düğüm sayısına ve bu düğümlerin karmaşıklığına bağlıdır. Ağaç öğrenme algoritmaları açgözlüdür; tüm kökten başlayıp her adımda en iyi nereden bölüneceğine bakılır. Bu bölmeler, kullanılan girdinin sürekli ya da kesikli olmasına göre öğrenme kümesini iki ya da $\mathrm{N}$ parçaya böler. Her bölümü kendi içinde öz çağrılı bir biçimde nasıl en iyi bölebileceğimizi araştırır, artık bölme gerekmediğinde durur ve bir yaprak düğümü oluşturulur (Alpaydın, 2011).

İK alanında karar ağacı örneklerine baktığımızda; Alao ve Adeyemo (2013) yeni çalışan yıpranma vakalarını tahmin etmek için kullanılan bir tahmine dayalı model geliştirmek için karar ağacı modellerini ve kural kümelerini kullanmıştır. Liu (2020), makalesinde, insan kaynakları yönetiminde veri madenciliğinde karar ağacı algoritmasının işlevini incelemekte ve insan kaynakları yönetimi modunu ve seçim faktörlerini analiz etmektedir.

\section{Rastgele orman}

Rastgele ormanlar, her ağacın bağımsız olarak örneklenen rastgele bir vektörün değerlerine bağlı olduğu ve ormandaki tüm ağaçlar için ayn dağılıma sahip olduğu, ağaç tahmin edicilerinin bir kombinasyonudur. Rastgele orman, en iyi sonucu seçmek için birden çok karar ağacını birleştiren sınıflandırma, regresyon ve diğer görevler için kullanılan bir öğrenme yöntemi olup eğitim kümesine çok fazla dayanan karar ağaçları modelinin doğruluğunu artırır. Bir ağaç sınıflandırıcı ormanının genelleme hatası, ormandaki tek tek ağaçların gücüne ve aralarındaki korelasyona bağlıdır (Breiman, 2001). Alduayj ve Rajpoot (2018), çalışanların yıpranmasını özelliklerine göre tahmin etmek için çeşitli çekirdek işlevleri, rastgele orman ve K-en yakın komşu (KNN) ile destek vektör makinesini (SVM) kullanmıştır. Frye, Boomhower, Smith, Vitovsky ve Fabricant (2018), temel bileşen analizi ve sınıflandırma yöntemlerini K-En Yakın Komşular ve Rastgele Orman uygulayarak, çalışanların işten ayrılmalarını en yüksek doğrulukla öngörmüşlerdir. Yadav, Jain ve Singh (2018) ile Srivastava ve Nair (2017), sınıflandırma tekniklerini kullanarak çalışanın kesin davranışlarını ve niteliklerini analiz ederek çalışan kaybını tahmin etmek için bir çerçeve sağlamıştır. El Rayes ve diğerleri (2020), tahmin edici analitik kullanarak gönüllü işten çıkarma ile ilgili olarak çalışanın yıpranmasını tahmin etmişlerdir ve Setiawan ve diğerleri (2020) ise çalışanların yıpranması üzerinde önemli bir etkisi olan on bir değişken bulmuştur.

\section{Destek vektör makineleri}

Vapnik tarafından 1995 yılında geliştirilen ve denetimli bir öğrenme algoritması olan Destek Vektör Makineleri, günümüzde en yaygın olarak kullanılan makine öğrenme tekniği tabanlı örüntü sınıflandırma yöntemidir. Sınıflandırma ve doğrusal olmayan fonksiyon problemlerinin çözümü için kullanılan bu yöntem istatistiksel öğrenme teorisine dayalıdır. Bu tekniğin temel amacı, farklı tipte çekirdek fonksiyonlarını kullanarak doğrusal olmayan ayrılabilir örnekleri başka bir yüksek boyutlu uzaya yansitmak ve sadece özellikleri verilen test kümesindeki veri örneklerinin hedef değerlerini tahmin eden bir model üretmektir. 


\section{Derin öğrenme}

Derin öğrenme makine öğrenmenin bir alt alanıdır ve sinir ağlarından oluşur. Derin öğrenmedeki "derin", girdileri ve çıktıyı içeren üçten fazla katmandan oluşan bir sinir ağını ifade eder ve bir derin öğrenme algoritması olarak kabul edilebilir. Derin öğrenme ve makine öğrenme arasındaki fark, her bir algoritmanın nasıl öğrendiği ile ilgilidir. Derin öğrenme, sürecin özellik çıkarma parçasının çoğunu otomatikleştirerek, gereken manuel insan müdahalesinin bir kısmını ortadan kaldırmakta ve daha büyük veri kümelerinin kullanılmasını sağlamaktadır. Derin öğrenme, "ölçeklenebilir makine öğrenme" olarak düşünülebilmektedir. Makine öğrenme, öğrenmek için daha çok insan müdahalesine bağlıdır. İnsan uzmanlar, veri girdileri arasındaki farkları anlamak için özelliklerin hiyerarşisini belirlemekte ve genellikle öğrenmek için daha fazla yapılandırılmış veri gerektirmektedir.

"Derin" makine öğrenme, algoritmasını bilgilendirmek için denetimli öğrenme olarak da bilinen etiketli veri kümelerinden yararlanabilir, ancak mutlaka etiketli bir veri kümesi gerektirmez. Yapılandırılmamış verileri ham biçiminde (örneğin; resim veya metin) alabilmekte ve farklı veri kategorilerini birbirinden ayıran özelliklerin hiyerarşisini otomatik olarak belirleyebilmektedir. Derin öğrenme, makine öğrenmeden farklı olarak, verileri işlemek için insan müdahalesi gerektirmez, bu da makine öğrenmeyi ölçeklendirmemize olanak tanımaktadır.

Derin öğrenme, bir bilgisayarı sinir ağı mimarisi aracılığıyla büyük miktarda veriden öğrenmesi için eğiten ve verileri soyutlama katmanlarına ayıran bir makine öğrenme dalıdır. Derin öğrenme, birden çok işleme katmanından oluşan hesaplama modellerinin, birden çok soyutlama düzeyiyle verilerin temsillerini öğrenmesine olanak tanır. Bu yöntemler, konuşma tanıma, görsel nesne tanıma, nesne algılama ve ilaç keşfi ve genomik gibi diğer birçok alanda en son teknolojiyi önemli ölçüde geliştirmiştir. Derin öğrenme, bir makinenin her katmandaki temsili önceki katmandaki temsilden hesaplamak için kullanılan dahili parametrelerini nasıl değiştirmesi gerektiğini belirtmek için geri yayılım algoritmasını kullanarak büyük veri kümelerinde karmaşık yapıyı keşfeder. Derin evrişimli ağlar görüntü, video, konuşma ve ses işlemede çı̆̆ır açarken, tekrarlayan ağlar metin ve konuşma gibi sıralı verilere 1şık tuttu (LeCun ve diğgerleri, 2015).

Derin öğrenme, insan kaynakları yönetimi alanında birçok yeniliklerin yolunu açmaktadır. Her şeyden önce, konuşma tanıma için önemli bir araçtır. Temel olarak, herhangi bir sanal asistan ve sohbet robotu, insan sesini işlemek ve buna göre yanıt vermek için bu algoritmaları kapsamlı bir şekilde kullanır. Bu, şirketlerin İK ile ilgili çeşitli süreçleri ve hizmetleri otomatikleştirmesine olanak tanıyarak onları daha hızlı ve günün her saatinde kullanılabilir hale getirir. ("HR and AI", 2021).

Derin öğrenmenin İK alanında diğer bir kullanım alanı ise Chatbot uygulamalarıdır (Jurafsky ve Martin, 2020). Chatbot; insanların bir sohbet ara yüzü aracılığıly etkileşime girdiği bir hizmettir. Diyalog sistemlerinin en basit türleri, yapılandırılmamış konuşmaları veya gayri resmi (informel) insan-insan etkileşiminin karakteristiği olan sohbetleri taklit etmek amacıyla uzun konuşmaları sürdürebilen sohbet robotlarıdır. Doğal dil işleme, insan dilini, tonunu ve bağlamı anlamak için sohbet robotlarını ve benzer sistemleri eğitir. İşletmeler, sohbet robotları ile İK hizmeti sunumunu otomatikleştirmeye devam ettiği sürece, doğal dil işleme ve yapay zekâ sistemleri için çok önemli bir yetenek olarak ortaya çıkacaktır. Chatbot'lar, sezgisel ve kullanımı kolay bir doğal dil insan-bilgisayar ara yüzü sağladıkları için son zamanlarda oldukça popüler hale gelmiştir.

Derin öğrenme yaygın bir şekilde konuşma ve görüntü tanıma alanlarında da kullanılmaktadır. Konuşma Tanıma (Otomatik Konuşma Tanıma (ASR) veya bilgisayar konuşma tanıma), bir bilgisayar programı olarak uygulanan bir algoritma aracılığıla bir konuşma sinyalini bir dizi kelimeye dönüştürme işlemidir. Konuşma tanımada, insan sesi girişlerini tanımak ve bunlara yanıt vermek için derin öğrenme algoritmaları tasarlanabilmektedir. Sanal asistanlar, insan sesini işlemek ve buna göre yanıt vermek için konuşma tanıma algoritmalarını kullanmaktadır. Görüntü veya video tanıma, herhangi bir adımda herhangi bir insan desteği olmadan makine öğrenme için görüntü işlemenin önemli bir uygulama alanıdır. Görüntü ve video tanımada derin öğrenme algoritmaları, nesne sınıflandırmasında yaygın bir şekilde kullanılmaktadır ve insanlardan daha iyi performans göstermektedirler. Binlerce başvuranın videoları ve fotoğrafları verilen derin öğrenme sistemleri, adayları nesnel verilere göre tanımlayabilmekte ve sinıflandırabilmektedir. Derin öğrenmenin bir diğer uygulaması, çalışanların ruh halini belirlemek ve rahatsızlık belirtilerini tespit etmek için davranış analizi ve görüntü tanıma ile ilgilidir. Sensörlere ve kameralara bağlı, derin öğrenme ile çalışan bir makine, personelin her zamanki davranışını incelemekte ve tekrar eden bazı örüntüleri tanıyabilmektedir. Bu örüntüler bozulursa, sistem bir şeylerin yanlış olduğunu anlayabilmektedir. 
Öneri motoru, belirli bir kullanıcıya veya müşteriye en alakalı öğeleri önermek için makine öğrenme algoritmalarını kullanan bir tür bilgi filtreleme aracıdır. Dijital öğrenme deneyimleri, genellikle beceri düzeyleri ve profesyonel ilgi alanları ile ilgili kişiselleştirilmiş öğrenme önerilerini içermektedir. Öğrenme deneyimi platformları, derin öğrenme ve büyük veriyi kullanarak bireysel çalışanların ilgisini çekebilecek öğrenme yollarını belirleyebilmektedir. Öneri motorları, örtük veya açık olarak toplanabilen bireysel davranış verilerinde örüntü bulma ilkesine göre çalışmaktadır (Sushman, 2021).

\section{Sonuç}

Günümüz yoğun rekabet ortamında işletmeler yaşamlarına devam edebilmek ve rekabet elde edebilmek için doğru stratejiler geliştirmek zorundadır. İşletmelerin rekabet avantajı sağlanmasında en önemli güç olarak görülen insan kaynaklarının seçilmesi ve yönetilmesi ise oldukça önem taşımaktadır. İşletmelerin yetenekli işgücünü kendilerine çekmede, uygun adayları bulmada ve seçmede, çalışanlarına uygun İK politika ve süreçleri belirlemede geleneksel İK yöntemleri ile başarılı olması günümüzde oldukça zordur. Diğer tüm fonksiyonlar gibi İK fonksiyonu da değişen teknolojik beklentilere ve ihtiyaçlara cevap verebilecek şekilde kendini yenilemek zorundadır. İK analitiği ve yapay zekâ yöntemleri, insan kaynakları alanının daha stratejik ve proaktif bir rol kazanmasında etkili yöntemler sağlamakta ve avantajlar sunmaktadır. İK bu yöntemler sayesinde kurumda yarattığ1 değeri daha net bir biçimde ortaya koyabilmekte ve üst yönetime sunabilmektedir. İK analitiği ve yapay zekâ, İK fonksiyonlarının kurumun hedeflerine ve stratejilerine uygun bir biçimde tasarlanabilmesi için IKK uygulamacılarına yol gösteren önemli öngörüler ve bilgiler sunabilmektedir. $\mathrm{Bu}$ yöntemlerin kullanımı ile hem zaman hem maliyet açısından tasarruf sağlayan kurumlar, en önemli güçleri olan insan çalışanlarını elde tutabilmekte ve işgücü devir oranının getireceği ek maliyetlerden korunabilmektedir.

Çalışma kapsamında İK analitiğinin önemi ve kullanım alanları incelenmiş ve yapay zekâ yöntemlerinin İK fonksiyonlarında ne amaçla kullanılıp, kurumlara ne gibi avantajlar sağladığı üzerinde durulmuştur. Ayrıca İK süreçlerinde kullanılan yapay zekâ yöntemleri detaylı bir şekilde açıklanmışır. Günümüzün en önemli ve gelişen konuları arasında bulunan İK analitiği ile yapay zekâ konusunu ele alan bu çalışma, yerli literatüre teorik anlamda önemli bir katkı sağlamakta ve hem İK uygulamacıları hem de bu alanda çalışma yapan akademisyenlere yol gösterici olmaktadır. Bununla beraber, söz konusu konuların ampirik olarak da uygulama örnekleri ile incelenmesi bundan sonra yapılacak çalışmalar için önerilmektedir. Uygulama alanından gelen örnekler ile konuyu Türk işletmeleri açısından kavramak ve değerlendirmek faydalı olacaktır.

\section{Hakem Değerlendirmesi / Peer-review:}

Diş bağımsız

Externally peer-reviewed

\section{Çıkar Çatışması / Conflict of interests:}

Yazar(lar) çıkar çatışması bildirmemiştir.

The author(s) has (have) no conflict of interest to declare.

\section{Finansal Destek / Grant support:}

Bu çalışma Yıldız Teknik Üniversitesi Bilimsel Araştırma Projeleri Koordinasyon Birimince Desteklenmiştir. Proje Numarası: 4540

This work was supported by Research Fund of the Yildiz Technical University. Project Number: 4540

\section{Yazar Katkıları / Author Contributions:}

Fikir/Kavram/Tasarım - Idea/Concept/Design: Y.B., M.B. Kaynak Taraması - Literature Review: Y.B., M.B. Makalenin Yazımı - Writing the Article: Y.B., M.B. Onay - Approval: Y.B., M.B. 


\section{Kaynakça / References}

Agrawal, R. \& Srikant, R. (1994). Fast Algorithms for Mining Association Rules. Proceedings of the 20th VLDB Conference, Santiago, Chile.

Ahmed, O. (2018). Artificial intelligence in HR. International Journal of Research and Analytical Reviews, 5 (4), 971-978.

Alao, D. \& Adeyemo, A.B. (2013). Analyzing employee attrition using decision tree algorithms. Computing, Information Systems and Development Informatics, 4(1), 17-28.

Alduayj., S. S., \& Rajpoot K. (2018). Predicting employee attrition using machine learning. 2018 Proceedings of International Conference on Innovations in Information Technology (IIT). IEEE, 93 98.

Alpaydın, E. (2011). Yapay Öğrenme. Boğaziçi Üniversitesi Yayınları, İstanbul.

Breiman, L. (2001). Random forests. Machine Learning. 45, 5-32.

Cheng, X. (2020). Obtain Employee Turnover Rate and Optimal Reduction Strategy Based on Neural Network and Reinforcement Learning. Publication eprint: arXiv:2012.00583.

Efe, M. Önder \& Kaynak, O. (2000). Yapay Sinir Ağları ve Uygulamaları. Boğaziçi Üniversitesi Yayınları, İstanbul.

El-Rayes, N., Fang, M., Smith, M. \& Taylor S.M. (2020). Predicting employee attrition using tree-based models. International Journal of Organizational Analysis. 28(6), 1273 - 1291.

Faliagka, E., Illiadis,L., Karydis, I., Rigou, M., Sioutas, S., Tsakaladis, A. \& Tzimas, G. (2014). On-line consistent ranking on e-recruitment: seeking the truth behind a well formed CV. Artificial Intelligence Review, 42 (3), 515-528.

Fitz-enz, J. (2009). Predicting people: from metrics to analytics. Employment Relations Today, 36 (3), 111.

Frye, A., Boomhower, C., Smith, M., Vitovsky, L. \& Fabricant, S. (2018). Employee attrition: what makes an employee quit? SMU Data Science Review. 1(1), 1 - 28.

Gartner Analytics Maturity Model. (2021). Erişim adresi: www.gartner.com.

Girmanova, L. \& Gasparova, Z. (2018). Analysis of data on staff turnover using association rules and predictive techniques. Quality Innovation Prosperity, 22 (2), 82-95.

Gurusinghe, R.N., Arachchige, B.J.H. \& Dayarathna, D. (2021). Predictive HR analytics and talent management: a conceptual framework. Journal of Management Analytics, 8 (2), 195-221.

Hamilton, R.H. \& Sodeman, W.A. (2020). The questions we ask: opportunities and challenges for using big data analytics to strategically manage human capital resources. Business Horizons, 63 (1), 85-95.

Heuvel, V.D.S. \& Bondarouk, T. (2017). The rise and fall of HR analytics. Journal of Organizational Effectiveness, People and Performance, 4 (2), 127-148.

HR and AI: Making Human Resources More With Algorithms. (2021). Erişim adresi: https://aprosoftware.com/hr-and-ai/

Jia, Q., Guo, Y., Li, R., Li, Y. \& Chen, Y. (2018). A conceptual artificial intelligence application framework in human resource management. ICEB Conference Proceedings 91.

Jurafsky, D. \& Martin, J.H. (2020). An Introduction to Natural Language Processing, Computational Linguistics and Speech Recognition, Pearson Education, USA.

Karimi-Majd, A.- M., Mahootchi, M. \& Zakery, A. (2017). A reinforcement learning methodology for a human resource planning problem considering knowledge-based promotion. Simulation Modelling Practice and Theory. (79), 87 - 99.

Karmanska, A. (2020). The benefits of HR analytics. Research Papers of Wroclaw University of Economics and Business, 64 (8), 30-40.

LeCun, Y, Bengio, Y \& Hinton, G. (2015). Deep learning. Nature. 521, 434-444. 
Levenson, A. \& Fink, A. (2017). Human capital analytics: too much data and analysis, not enough models and business insight. Journal of Organizational Effectiveness: People and Performance, 4 (2), 145-156.

Liu, Y. (2020). Analysis of human resource management mode and its selection factors based on decision tree algorithm. International Conference on Advance in Ambient Computing and Intelligence Proceedings. IEEE.

Maimon, O. \& Rokach, L. (2010). The Data Mining and Knowledge Discovery Handbook. Springer Science.

Margherita, A. (2021). Human resources analytics: a systematization of research topics and directions for future research. Human Resource Management Review,

Marler, J. \& Boudreau, J. (2017). An evidence based review of HR analytics. The International Journal of Human Resource Management, 28 (1), 3-26.

Matyunina, J. (2020). How machine learning is changing HR industry? Erişim adresi: https://codetiburon.com/ machine-learning-changing-hr-industry/

McCarthy, J. (2004). What is Artificial Intelligence? Stanford University, Computer Science Department. (www-formal.stanford.edu/jmc(whatisai.pdf).

Merlin, R. \& Jayam, R. (2018). Artificial intelligence in human resource management. International Journal of Pure and Applied Mathematics, 119 (17), 1891-1895.

Mitchell, M.T. (1997). Machine Learning. McGraw Hill.

Mortensen, M. J., Doherty, N.F. \& Robinson, S. (2015). Operational research from taylorism to terabytes: a research agenda for the analytics age. European Journal of Operational Research, 241 (3), 583-595.

Murgai, A. (2018). Role of artificial intelligence in transforming human resource management. International Journal of Trend In Scientific Research and Development, 2(3), 877-881.

Narula, S. (2015). HR analytics, its use, techniques and impact. International Journal of Research in Commerce \& Management, 6 (8), 47-53.

Pağda, Z. (2018). Yapay zekâ ve insansız insan kaynakları. Harvard Business Review, 103-107.

Pwc. (2017). Artificial intelligence in HR: a no-brainer. Erişim adresi: https://www.pwc.nl/nl/assets/documents/artificial-intelligence-in-hr-a-no-brainer.pdf.

Quinlan, J.R. (1986). Induction of decision trees. Machine Learning, 1, 81-106.

Russell, S. \& Norvig, P. (2010). Artificial Intelligence: A Modern Approach, Third Edition. Prentice Hall, USA.

Setiawan, I., Suprihanto, S., Nugraha, A.C. \& Hutahaean, J. (2020). HR analytics: Employee attrition analysis using logistic regression. IOP Conference Series: Mater. Sci. and Engineering. 830(3), 1 - 7.

Sharma, A. \& Sharma, T. (2017). HR analytics and performance appraisal system: a conceptual framework for employee performance improvement. Management Research Review, 40 (6), 684697.

Sooraska, N. (2021). A survey of using computational intelligence and artificial intelligence in human resource analytics. 7th International Conference on Engineering, Applied Sciences and Technology. 1-3 Nisan 2021, Pattaya, Tayland.

Srivastava, K. D. \& Nair, P. (2017). Employee attrition analysis using predictive techniques. Proceedings of International Conference on Information and Communication Technology for Intelligent Systems. Springer, Cham. 293 - 300.

Strohmeier, S., \& Piazza, F. (2015). Artificial intelligence techniques in human resource Management- a conceptual exploration. In Intelligent Techniques in Engineering Management, 149-172, Springer, Cham.

Sushman, B. (2021). The beginners guide to AI in HR. Erişim adresi: https:/ / www.toolbox.com/hr/hr-innovation/articles/the-beginners-guide-to-ai-in-hr/

Turing A. (1950). Computing machinery and intelligence. Mind, 49, 433 - 460. 
Van Vulpen, E. (2019). The Basic Principles of People Analytics. Academy to Innovative HR, AIHR. Erişim adresi: https://www. aihr.com/resources /The_Basic_principles_of_People_Analytics.pdf

Vapnik, V. (1995). The Nature of Statistical Learning Theory. Springer-Verlag, New York, USA.

Writer, S. (2018). 3 Ways machine learning can transform HR. Erişim adresi: https://www.hrtechnologist.com/articles/digital-transformation/futures-at-the-door-whymachine-learning-can-transform-hr/

Yadav, S., Jain, A. \& Singh, D. (2018). Early Prediction of Employee Attrition using Data Mining Techniques. Proceedings of IEEE 8th International Advance Computing Conference (IACC), 349 354.

Yang, S. \& Islam, Md.T. (2020). IBM Employee Attrition Analysis. Publication eprint: arXiv:2012.01286 